\title{
Ownership Structure, Corporate Governance and Dividend Policy: Evidence from Indonesia
}

Ronny Malavia Mardani,1,2, Moeljadi¹, Sumiati1, and Nur Khusniyah Indrawati

${ }^{1}$ Universitas Brawijaya

${ }^{2}$ LPDP

\section{Abstract}

The purpose of this study is to examine the relationship between ownership structure, corporate governance, and dividend policy. The sample in this study is a financial company listed on the Indonesia Stock Exchange in the period 2014-2016. The results showed that managerial ownership is positively related to dividend policy. Institutional ownership is negatively related to dividend policy. Board size is negatively related to dividend policy, while independent board is positively related to dividend policy.

Keywords: managerial ownership, institutional ownership, board size, independent board
Ronny Malavia Mardani ronny.malavia.mardani@ gmail.com

Received: 29 August 2018 Accepted: 18 September 2018 Published: 11 November 2018

Publishing services provided by Knowledge

(c) Ronny Malavia Mardani et al. This article is distributed under the terms of the Commons Attribution License, which permits unrestricted use and redistribution provided that the original author and source are credited.

Selection and Peer-review under the responsibility of the ICOI-2018 Conference Committee.

\section{S OPEN ACCESS}

\section{Introduction}

The debate over dividend policy was initiated by Gordon (1959), Lintner (1956) and Miller dan Modigliani (1961), which remains a controversial issue today. Black (1976) in his "The Dividend Puzzle" supported Kinkki (2001) cannot explain what a company should do about dividend policy. Some studies offer an alternative and interesting approach as a solution. Much of the research is rooted in information asymmetry between insiders and outsiders as well as ownership and control structures. In agency theory frameworks, Crutchley dan Hansen (1989) suggest one way to reduce the cost of equity agents is by increasing dividends (Easterbrook, 1984; Rozeff, 1982). A larger dividend payout will increase the chances of an increase in external equity capital, so that the activity of the manager will be monitored by the stock exchange, stock commissions, investment bankers, and new capital providers. This monitoring encourages managers to act more in line with the interests of shareholders. Jensen dan Meckling (1976) argue that conflicts between principals and agents occur because they act for their own interests. However, unlike in developed countries, agency problems occur between majority shareholder and minority (Claessens et al., 2000; La Porta et al., 
2000). Majority shareholders tend to take over minority shareholders. That is why good corporate governance is needed to protect minority shareholders right.

There are two theories in the relationship between corporate governance and dividend policy: outcome and substitution (La Porta et al., 2000). In the theory of outcome mentioned that there is a positive relationship between corporate governance with dividend policy (Kowalewski et al., 2007; La Porta et al., 2000). On the other hand, in the substitution theory mentioned that the weaker corporate governance practice, the company will provide higher dividends (Renneboog dan Szilagyi, 2006).

In Indonesia, the government has issued strong regulations in encouraging companies to implement good corporate governance. However, until this time, Indonesian firms are still relatively weak in the implementation of good corporate governance. In 2015, Indonesia was only able to place its two companies in the list of 50 Best Issuers in Good Corporate Governance Practices in ASEAN in the awarding of the ASEAN Corporate Governance Awards 2015 organized by the ASEAN Capital Markets Forum (ACMF) in Manila, Philippines, under Thailand, Singapore and Malaysia. This study follows the recommendations of Setiawan dan Kee Phua (2013), using the financial firm as the research sample.

\section{Theoritical Review}

Jensen dan Meckling (1976) argue that a conflict of interest exists between the principal and the agent because they act for their own interests. However, in developing countries, agency problems also occur between majority shareholders and minority shareholders (Claessens et al., 2000; La Porta et al., 2000). Therefore, good corporate governance mechanism is needed to protect the interests of minority shareholders, such as dividends payment. In previous research, ownership is one of the important variables that influences dividend payout ratio (Kumar, 2006). Managerial ownership positively related to dividend payout ratio, while institutional ownership negatively related to dividend payout ratio. Al-Najjar dan Kilincarslan (2016) found that institutional investors is negatively related to dividend payment, while board size has a positive effect on dividend payment

Bokpin (2011) in his research on the Ghana Stock Exchange found that insider ownership, board size and independent board has a positive effect on dividend policy. Roy (2015) found that institutional investors negatively affect dividend payout, while board size and independent board have positive effect on dividend payout. Setiawan dan Kee 
Phua (2013) in his research found that board size was negatively related to dividend policy

Based on the literature review that has been described previously, the hypothesis in this study:

$\mathrm{H}_{1}$ : Managerial ownership is positively related to dividend policy

$\mathrm{H}_{2}$ : Institutional ownership is negatively related to dividend policy

$\mathrm{H}_{3}$ : Board Size is negatively related to dividend policy

$\mathrm{H}_{4}$ : The Independent Board is positively related to dividend policy

\section{Research Methodology}

We select our sample from financial firm that listed at Indonesian Stock Exchange that announce dividend from 2014-2016 periods. In order to measure corporate governance practice, we use board size and independent board. To test the hypothesis, we applies regression analysis:

$$
D P R=a+b_{1} M O W N+b_{2} I N S T+b_{3} B Z+b_{4} I N D B+e
$$

1. $\mathrm{DPR}=$ Dividend Payout Ratio

2. MOWN = Managerial Ownership

3. INST = Institutional Ownership

4. $B Z=$ Board size

5. INDB = Independent Board

\section{Discussion}

The sample in this study is a financial firm listed in Indonesia Stock Exchange which announces dividend payment in the period of 2014-2016. The financial firm selected as the research sample is a recommendation of previous research (Setiawan dan Kee Phua, 2013). Financial companies listed on the Indonesia Stock Exchange are $79 \mathrm{com}$ panies, and only 27 companies are announcing dividend payment during 2014-2016. Total observations are 81 firm-year observations. The following table presents the descriptive statistics of this research. 
TABLE 1: Descriptive Statistics.

\begin{tabular}{|c|c|c|c|}
\hline & Minimum & Maximum & Mean \\
\hline MOWN & 0,00 & 67,90 & 2,5148 \\
\hline INST & 0,00 & 90,34 & 23,1544 \\
\hline BS & 6,00 & 20,00 & 10,8395 \\
\hline INDB & 0,14 & 0,40 & 0,2417 \\
\hline DPR & 5,03 & 91,15 & 34,9923 \\
\hline
\end{tabular}

From Table I, the descriptive statistics for managerial ownership show that the actual range is $0 \%$ to $67,9 \%$, with a mean of $2,5148 \%$. This result show that the existence of managerial ownership in the ownership structure of financial firm is very low. institutional ownership is in the range of $0 \%$ to $90.34 \%$ with a mean of $23.1544 \%$. Board size is in range 6 to 20, with a mean of 10,8395. Mean board size is high enough, CEOs will be more difficult in leading and controlling councils as the number of boards increases over 10 members. The opportunity for each individual in the council to exert influence in decision-making becomes more limited and any meetings made become more uncontrollable (Harper, 2007). Although, with a larger number of board members increasing the number of expert skills and abilities of the board, it is often more difficult to coordinate because of the greater number of interactions among members (Goodstein et al., 1994). Independent Board is in range 0,14 to 0,4, with a mean of 0,2417. Companies in Indonesia Stock Exchange are required to have an independent board composition of at least 30\%. Companies in Indonesia Stock Exchange are required to have an independent board composition of at least 30\%. thus the average composition of independent board in the sample company is below 30\%. This shows the weak of good corporate governance practice by companies in Indonesia Stock Exchange.

TABle 2: Regression Analysis.

\begin{tabular}{l|ccc} 
Variable & Coefficient & $T_{\text {Value }}$ & Sig. \\
MOWN & 0,178 & 1,137 & $0,259^{*}$ \\
INST & $-0,045$ & $-0,726$ & $0,470^{*}$ \\
BS & $-3,066$ & $-3,070$ & $0,003^{*}$ \\
INDB & 10,015 & 3,195 & $0,002^{*}$ \\
Notes: * Significant 1 per cent; $\Pi=81 ;$ MOWN = Managerial OWnership; INST \\
$=$ Institutional Ownership; BS = Board size; INDB = Independent Board; DPR = \\
Dividend Payout
\end{tabular}

From table 2, Managerial Ownership is positively related to dividend policy (insignificant). These results confirm the findings of Kumar (2006) and Bokpin (2011), who found 
a positive correlation between managerial ownership and dividend policy. This suggests that improving managerial ownership at some threshold, will make the insider feel no more benefit to increase dividend payouts. These results support the entrenchment hypotheses (Fama dan Jensen, 1983). Based on this result, $H_{1}$ is accepted'

Institutional ownership is negatively related to dividend policy (insignificant). These results also confirm the findings of Kumar (2006) and Roy (2015), who found a negative correlation between institutional ownership and dividend policy. This is in line with the behavior of institutional investors, as institutional investors are also the creditor of the company, so they are very concerned to protect their credit. Based on this result, $\mathrm{H}_{2}$ is accepted

Board size negatively correlated to dividend policy (significant at 1\%). These results confirm the findings of Setiawan dan Kee Phua (2013) who found a negative correlation Board size and dividend policy. This shows the weak implementation of good corporate governance in financial firm. Based on this result, $\mathrm{H}_{3}$ is accepted

Independent board is positively related to dividend policy (significant at 1\%). These results are in line with the findings of Bokpin (2011) who found a positive correlation between Independent board and dividend policy. This indicates that an increase in the board of independent commissioners will encourage the company to pay a larger dividend. Based on this result, $\mathrm{H}_{4}$ is accepted

\section{Conclusion}

The percentage of shares owned by the manager greatly affects the payment of dividends. In the Indonesian financial firms, the insider ownership is very low. This causes managers are reluctant to make dividend payments. Statistically only 27 financial companies are paying dividends throughout 2014-2016 from 79 listed financial firm in Indonesia Stock Exchange. These results are in line with Crutchley dan Hansen (1989) which states that an increase in the percentage of share ownership by managers, will make managers motivated to improve performance and more responsibly improve shareholder wealth through dividend payouts.

The low implementation of good corporate governance in Indonesia has an impact on dividend policy in accordance with the findings of Setiawan dan Kee Phua (2013). Indonesian financial firms tend to compensate their poor corporate governance through higher dividend payment. There is a negative effect of board size on dividend payment. Therefore this research confirms the application of substitution theory in Indonesia rather than outcome theory. However, on the other hand, the existence 
of an independent board of commissioners encourages companies to make larger dividend payments.

Limitation in this study: the number of financial companies that make dividend payments only $34.1 \%$ of 79 companies. In the future research is recommended to extend the time of the study, so that obtained data and better results

\section{References}

[1] Al-Najjar, B., dan Kilincarslan, E. (2016). The effect of ownership structure on dividend policy: evidence from Turkey. Corporate Governance: The international journal of business in society, 16(1), 135-161. doi: doi:10.1108/CG-09-2015-0129

[2] Black, F. (1976). The dividend puzzle. Journal of portfolio management, 2(2), 5-8.

[3] Bokpin, G. A. (2011). Ownership structure, corporate governance and dividend performance on the Ghana Stock Exchange. Journal of Applied Accounting Research, 12(1), 61-73. doi: doi:10.1108/09675421111130612

[4] Claessens, S., Djankov, S., dan Lang, L. H. P. (2000). The separation of ownership and control in East Asian Corporations. Journal of Financial Economics, 58(1), 81-112. doi: https://doi.org/10.1016/S0304-405X(00)00067-2

[5] Crutchley, C. E., dan Hansen, R. S. (1989). A Test of the Agency Theory of Managerial Ownership, Corporate Leverage, and Corporate Dividends. Financial Management, 18(4), 36-46. doi: 10.2307/3665795

[6] Easterbrook, F. H. (1984). Two agency-cost explanations of dividends. The American Economic Review, 74(4), 650-659.

[7] Fama, dan Jensen, M. C. (1983). Separation of Ownership and Control. The Journal of Law \& Economics, 26(2), 301-325.

[8] Goodstein, J., Gautam, K., dan Boeker, W. (1994). The effects of board size and diversity on strategic change. Strategic Management Journal, 15(3), 241-250.

[9] Gordon, M. J. (1959). Dividends, earnings, and stock prices. The Review of Economics and Statistics, 99-105.

[10] Harper, J. (2007). Chairing the Board: A Practical Guide to Activities \& Responsibilities: Kogan Page Publishers.

[11] Jensen, dan Meckling, W. H. (1976). Theory of the firm: Managerial behavior, agency costs and ownership structure. Journal of Financial Economics, 3(4), 305-360. doi: http://dx.doi.org/10.1016/0304-405X(76)90026-X

[12] Kinkki, S. (2001). Dividend puzzle-a review of dividend theories. Liiketaloudellinen aikakauskirja, 58-97. 
[13] Kowalewski, O., Stetsyuk, I., dan Talavera, 0. (2007). Does corporate governance determine dividend payouts in Poland? Post-Communist Economies, 20(2), 203-218. doi: $10.1080 / 14631370802018973$

[14] Kumar, J. (2006). Corporate Governance and Dividends Payout in India. Journal of Emerging Market Finance, 5(1), 15-58. doi: 10.1177/097265270500500102

[15] La Porta, R., Florencio, L.-d.-S., Shleifer, A., dan Vishny, R. W. (2000). Agency Problems and Dividend Policies around the World. The Journal of Finance, 55(1), 1-33.

[16] Lintner, J. (1956). Distribution of Incomes of Corporations Among Dividends, Retained Earnings, and Taxes. The American Economic Review, 46(2), 97-113.

[17] Miller, M. H., dan Modigliani, F. (1961). Dividend Policy, Growth, and the Valuation of Shares. The Journal of Business, 34(4), 411-433.

[18] Renneboog, L., dan Szilagyi, P. G. (2006). How relevant is dividend policy under low shareholder protection? Journal of International Financial Markets, Institutions and Money.

[19] Roy, A. (2015). Dividend policy, ownership structure and corporate governance: An empirical analysis of Indian firms. Indian Journal of Corporate Governance, 8(1), 1-33.

[20] Rozeff, M. S. (1982). Growth, beta and agency costs as determinants of dividend payout ratios. Journal of financial Research, 5(3), 249-259.

[21] Setiawan, D., dan Kee Phua, L. (2013). Corporate governance and dividend policy in Indonesia. Business Strategy Series, 14(5/6), 135-143. doi: doi:10.1108/BSS-01-20130003 